Article

\title{
A Waterfront View of Coastal Hazards: Contextualizing Relationships among Geographic Exposure, Shoreline Type, and Hazard Concerns among Coastal Residents
}

\author{
Steven B. Scyphers ${ }^{1, *}$, Michael W. Beck ${ }^{2}$, Kelsi L. Furman ${ }^{1}$, Judy Haner ${ }^{3}$, Lauren I. Josephs ${ }^{1,4}$, \\ Rebecca Lynskey ${ }^{1}$, Andrew G. Keeler ${ }^{5}$, Craig E. Landry ${ }^{6}$, Sean P. Powers ${ }^{7}$, Bret M. Webb ${ }^{8}$ and \\ Jonathan H. Grabowski ${ }^{1}$ \\ 1 Department of Marine \& Environmental Sciences, Northeastern University, Coastal Sustainability Institute, \\ Nahant, MA 01908, USA; furman.ke@husky.neu.edu (K.L.F.); lauren_josephs2@uri.edu (L.I.J.); \\ lynskey.r@husky.neu.edu (R.L.); j.grabowski@northeastern.edu (J.H.G.) \\ Institute of Marine Sciences, University of California, Santa Cruz, CA 95064, USA; mwbeck@ucsc.edu \\ The Nature Conservancy, Alabama Coastal Program, Mobile, AL 36602, USA; jhaner@tnc.org \\ 4 Department of Fisheries, Animal and Veterinary Sciences, University of Rhode Island, \\ Kingston, RI 02881, USA \\ 5 Department of Coastal Studies, East Carolina University, Wanchese, NC 27981, USA; keelera@ecu.edu \\ 6 Department of Agricultural \& Applied Economics, University of Georgia, Athens, GA 30602, USA; \\ clandry@uga.edu \\ 7 Department of Marine Sciences, University of South Alabama, Mobile, AL 36688, USA; spowers@disl.org \\ 8 Department of Civil Engineering, University of South Alabama, Mobile, AL 36688, USA; \\ bwebb@southalabama.edu \\ * Correspondence: s.scyphers@northeastern.edu; Tel.: +1-781-581-7370
}

Received: 1 October 2019; Accepted: 12 November 2019; Published: 26 November 2019

check for updates

\begin{abstract}
Coastal communities exist on the front lines of diverse natural hazards and the growing impacts of climate change. While traditional strategies for dealing with coastal hazards have often involved the hardening or armoring of shorelines, more recent research and practice have demonstrated the value and cost-effectiveness of "living shorelines" and other ecosystem-based strategies for coastal protection. To explore potential relationships among geographic exposure (waterfront vs. inland), shoreline condition (armored vs. natural), and hazard concerns, we surveyed 583 waterfront and inland residents in the northern Gulf of Mexico. We found that overall concern for coastal hazards was similar across waterfront and inland residents, as well as among residents with both armored and natural shorelines. However, concern for specific hazards differed across these groups. Waterfront residents were significantly more concerned about major hurricanes and erosion than inland residents. Conversely, inland residents were more concerned with drought and flooding than waterfront residents. Among waterfront residents, specific hazard concerns were similar between residents with natural and armored shorelines with two key exceptions. Residents with armored shorelines reported higher concern for erosion and sea level rise than residents with natural shorelines. Our results suggest that armored shorelines do not necessarily alleviate concerns about coastal hazards. In the context of balancing social and ecological objectives in addressing coastal hazards or adapting to climate change, understanding the perceptions and behaviors of coastal residents is essential for conserving and protecting coastal ecosystems along residential shorelines.
\end{abstract}

Keywords: coastal hazards; stakeholder decision-making; coastal management; hurricanes; climate adaptation 


\section{Introduction}

On the front lines of erosion, sea level rise, and hurricanes, coastal communities provide a lens into the historical and projected future costs and consequences of coastal hazards and climate adaptation [1-3]. In the United States alone, approximately 1.3 million people, including 30,000 families below the poverty line and 250,000 elderly people, reside in the highest quartile of exposure to coastal hazards [4]. In the aftermath of storms and other punctuating hazard events, coastal adaptation conversations often focus on migration, retreat, and fortifying coastlines. However, individual coastal residents continually deal with the threat of coastal hazards and also make decisions that impact the sustainability of coastal ecosystems. As such, scientists, engineers, conservationists, and policy-makers are intensely focused on understanding the influences of exposure and shoreline condition on coastal hazards [5,6], as well as the role of coastal property owners in brokering risk through their decisions to manage their coastlines [2].

Traditionally, a primary response to coastal hazards has involved building shoreline infrastructure such as bulkheads, seawalls, and revetments (Figure 1). Shoreline armoring is typically implemented to protect coastal property from hazards like erosion and flooding but can also be motivated by other social and biophysical influences $[4,7,8]$. In the United States, artificial shoreline structures cover $22,000 \mathrm{~km}$ and upwards of $90 \%$ of shorelines in many urban areas [9]. The economic costs and ecological consequences of shoreline armoring have been widely described and include increased erosion on adjacent properties, altered depth profiles and sediment transport, and the loss of ecologically important coastal habitats [10]. Nonetheless, many waterfront residents prefer hardened shorelines and prioritize perceived cost-effectiveness above environmental concerns [11,12].
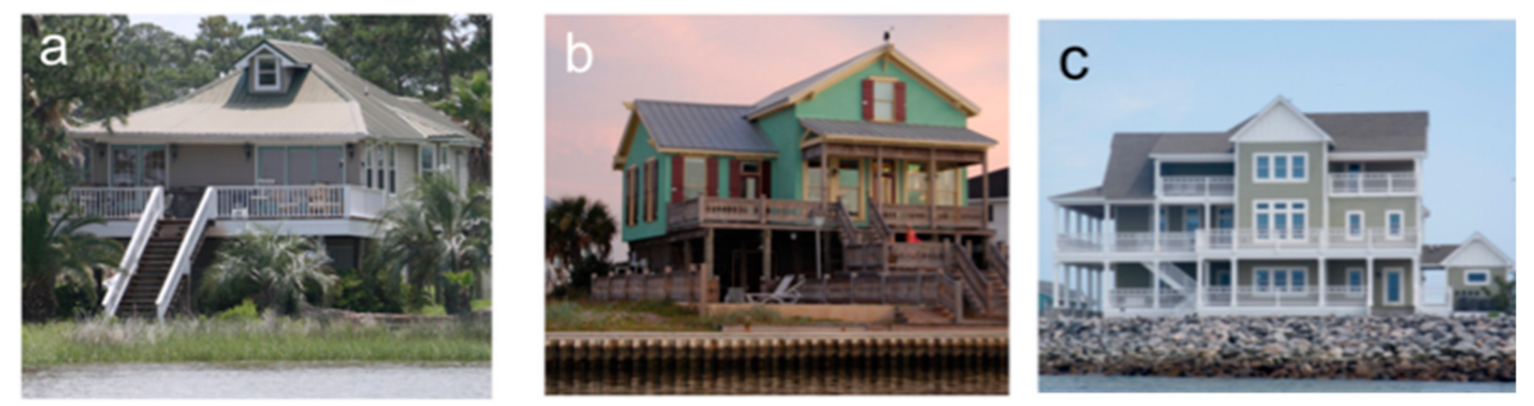

Figure 1. Photographs of waterfront homes with shorelines representing natural (a), vertical wall (b), and rip-rap revetment (c) shorelines. Photo Credits: S. Scyphers (a,b) and R. Gittman (c).

More recently, scientists and practitioners have been describing the benefits of nature-based strategies, including natural defenses and "living shorelines" for restoring degraded coastal ecosystems and mitigating risks $[13,14]$. In their natural condition, shorelines are often comprised of biogenic habitats such as saltmarshes, mangroves, and oyster reefs. These natural coastal habitats are widely valued for their environmental benefits, including the provision of essential habitat for marine life, promotion of favorable water quality, and reduction of shoreline erosion and flooding by attenuating waves, stabilizing sediments, and dampening surge $[13,15,16]$. Recent reviews of the protective value of wetlands found that vegetated shorelines can significantly reduce wave height and promote shoreline stabilization [17], and can be cost-effective for coastal protection [18]. Unfortunately, many coastal habitats have suffered dramatic declines, hampering the provision of ecosystem services [19]. Much of this loss is related to modification of coastal landscapes and shorelines for human development. Thus, understanding the perceptions and behaviors of coastal residents is essential for conserving and protecting these ecologically valuable habitats.

In this paper, we present survey data to address two key questions related to waterfront resident perceptions of coastal hazards and the broader implications of coastal development for sustainability along coastlines. First, how does waterfront exposure influence the overall and hazard-specific concerns of coastal residents? Second, among waterfront residents, does shoreline condition influence the 
level of concern, both overall and hazard-specific? For these questions, we analyzed survey data measuring individual concern for eight types (or intensities) of common coastal hazards and created an "Overall Hazards Concern" (OHC) index. We hypothesized that overall hazard concern would be greater among waterfront than inland residents and that shoreline hardening would generally mitigate hazard concern.

\section{Materials and Methods}

We conducted mixed-mode surveys of 583 coastal residents (400 inland and 183 waterfront) along Mobile Bay, Alabama and Pensacola Bay, Florida in the northern Gulf of Mexico (Figure 2) in 2014. The results described in this paper were collected from a series of questions aimed at exploring relationships among geographic exposure (inland, waterfront), shoreline type (waterfront residents only), and concerns for coastal hazards. We measured concern for eight types of coastal hazards on a scale from 1 (not at all concerned) to 5 (extremely concerned) for: category 1-2 hurricanes, category 3-4 hurricanes, category 5 hurricanes, droughts, erosion, floods (not from surges), habitat degradation, and sea level rise. The survey instrument also included socio-demographic questions to document gender, age, annual household income, education, environmental dependence, years at current residence, and years lived on coastal waters.

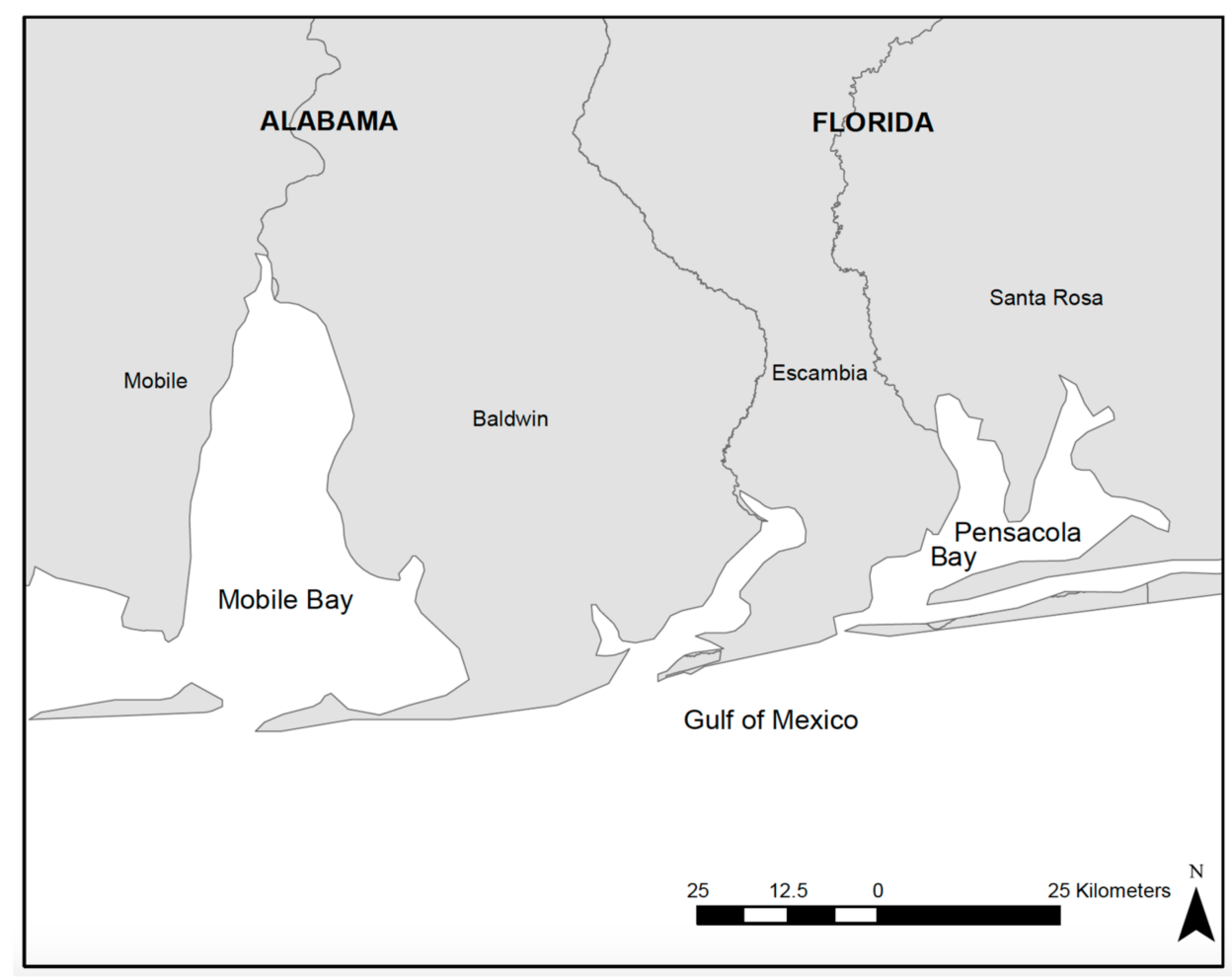

Figure 2. Map of study system involving four counties in coastal Alabama and West Florida.

Both inland and waterfront coastal residents were surveyed using a standardized survey instrument that was developed and pretested by an interdisciplinary team of coastal scientists and practitioners, and then pretested again with waterfront homeowners. The sample of 400 inland residents was recruited through Qualtrics Panel Research. The panel sample was proportioned to the general public and randomized before the survey was deployed. Waterfront homes were identified using Google Earth Pro and county tax assessor websites, and a random sample was selected from that frame. Public real estate websites (e.g., Zillow, Realtor.com) were used to identify and exclude properties that had been listed or sold during the previous 12 months. The sample of waterfront residents was recruited using a modified Dillman method [20] involving an initial mailing 
of 1000 postcard invitations to complete an online survey and three follow-up reminder postcards. Printed surveys were mailed to $20 \%$ of the online sample and all additional individuals who requested them. For all participants, the online survey was hosted and administered using Qualtrics Research Suite, which also served as the database for mail-returned surveys. The waterfront resident survey had an adjusted response rate of $21 \%$ and a mean completion rate of $83 \%$. The online version of the survey had a mean completion time of 20 minutes.

To explore overall patterns of concern across groups, we created an "Overall Hazard Concern" index (OHC) by aggregation of the eight individual coastal hazard concerns and tested it for internal reliability using Cronbach's $\alpha$. We then used Mann-Whitney $U$ tests to compare overall concern between geographic exposure (inland, waterfront) and shoreline type (natural, armored) groups. Next, we used bivariate correlations to examine potential relationships between socio-demographical characteristics and OHC. Lastly, we used Mann-Whitney $U$ tests to assess relative concern for specific hazards between groups.

\section{Results}

\subsection{Survey Sample and Demographics}

Our survey sample includes waterfront $(n=183)$ and inland $(n=400)$ residents of four coastal counties in Alabama and Florida (Table 1). Compared to inland residents, the waterfront sample was predominantly older (mean age: 65 waterfront, 48 inland), male (64\% waterfront, 39\% inland), white (98\% waterfront, $86 \%$ inland), with higher education degrees (graduate degree: $47 \%$ waterfront, $19 \%$ inland), and wealthier (household income $>\$ 100 \mathrm{k}$ : $53 \%$ waterfront, $18 \%$ inland). Both groups were similar in political orientation, with $19-22 \%$ identifying as liberal and $44-56 \%$ identifying as conservative. Both groups were also similar in the dependence on environmental quality, with $10-11 \%$ of respondents perceiving their occupations to depend "a great deal" on healthy coastal ecosystems. Among waterfront residents, $67 \%$ of residents had artificial structures (vertical walls, rip-rap revetment, rip-rap), whereas $33 \%$ of residents reported a natural shoreline.

Table 1. Survey demographics and descriptives. Coding used for categorical variables in Pearson correlations is shown in parentheses.

\begin{tabular}{lcc}
\hline & Inland & Waterfront \\
\hline Sample Size & 400 & $\mathbf{1 8 3}$ \\
Alabama (1) & 191 & 97 \\
Florida (2) & 209 & 86 \\
Age & & \\
Mean & 48 & 65 \\
Gender & & \\
Male (1) & $39 \%$ & $64 \%$ \\
Female (2) & $61 \%$ & $36 \%$ \\
Race & & \\
White (1) & $86 \%$ & $98 \%$ \\
Black (2) & $7 \%$ & $0 \%$ \\
Hispanic (2) & $3 \%$ & $0 \%$ \\
Asian (2) & $3 \%$ & $1 \%$ \\
Other (2) & $1 \%$ & $1 \%$ \\
Education & & \\
High School diploma or less (1) & $16 \%$ & $3 \%$ \\
Some college or 2-year degree (2) & $38 \%$ & $23 \%$ \\
Bachelor's degree (3) & $27 \%$ & $27 \%$ \\
Master's degree or more (4) & $19 \%$ & $47 \%$ \\
\hline
\end{tabular}


Table 1. Cont.

\begin{tabular}{lcc}
\hline & Inland & Waterfront \\
\hline Income & & \\
$\$ 25 \mathrm{k}$ or less $(1)$ & $15 \%$ & $5 \%$ \\
$\$ 25,001$ to $\$ 35 \mathrm{k}(2)$ & $14 \%$ & $3 \%$ \\
$\$ 35,001$ to $\$ 50 \mathrm{k}(3)$ & $17 \%$ & $7 \%$ \\
$\$ 50,001$ to $\$ 75 \mathrm{k}(4)$ & $20 \%$ & $15 \%$ \\
$\$ 75,001$ to $\$ 100 \mathrm{k}(5)$ & $16 \%$ & $17 \%$ \\
$\$ 100,001$ to $\$ 150 \mathrm{k}(6)$ & $12 \%$ & $20 \%$ \\
$\$ 150,001$ to $\$ 250 \mathrm{k}(7)$ & $5 \%$ & $16 \%$ \\
More than $\$ 250 \mathrm{k}(8)$ & $1 \%$ & $17 \%$ \\
Environmental Dependence & & \\
Not at all (1) & $59 \%$ & $71 \%$ \\
Only a little (2) & $16 \%$ & $12 \%$ \\
A fair amount $(3)$ & $14 \%$ & $7 \%$ \\
A great deal (4) & $11 \%$ & $10 \%$ \\
Political Stance & & \\
Very liberal (1) & $7 \%$ & $7 \%$ \\
Somewhat liberal (2) & $15 \%$ & $12 \%$ \\
Moderate/Middle of the road (3) & $34 \%$ & $25 \%$ \\
Somewhat conservative (4) & $25 \%$ & $33 \%$ \\
Very Conservative (5) & $19 \%$ & $23 \%$ \\
Years Living on the Water & & \\
Mean & & 20 \\
\hline
\end{tabular}

\subsection{Waterfront Exposure, Shoreline Condition, and Hazard Concern}

The OHC included eight variables (Table 2). Across all respondents, major hurricanes were the most worrisome hazards, while sea level rise and droughts were among the least concerning hazards. Notably, coastal habitat degradation and erosion were, on average, more concerning than category 1-2 hurricanes or floods.

Table 2. Scale descriptives reflecting concern for coastal hazards $(1=$ Not at all concerned: 5 = Extremely concerned).

\begin{tabular}{cccccc}
\hline Overall Hazard Index (OHC) & $\mathbf{N}$ & Mean & SD & $\alpha$ & $\Delta \boldsymbol{\alpha}$ \\
\hline & & & & $\mathbf{0 . 8 3}$ & \\
Cat. 5 hurricanes & 560 & 4.58 & 0.84 & & 0.85 \\
Cat. 3-4 hurricanes & 560 & 4.37 & 0.89 & & 0.84 \\
Habitat degradation & 560 & 4.05 & 0.98 & & 0.83 \\
Erosion & 560 & 3.83 & 1.11 & & 0.84 \\
Cat. 1-2 hurricanes & 560 & 3.72 & 1.12 & & 0.85 \\
Floods (not from surges) & 560 & 3.52 & 1.22 & & 0.83 \\
Sea level rise & 560 & 3.33 & 1.31 & & 0.83 \\
Droughts & 560 & 3.27 & 1.24 & & 0.83 \\
\hline
\end{tabular}

When comparing overall concern represented by the $\mathrm{OHC}$, we found that concern was similar between waterfront and inland residents of coastal counties $(n=560, Z=0.219, P=0.827)$, as well as similar among homeowners with armored and natural shorelines $(n=170, Z=1.566, P=0.117$; Figure 3).

Among inland residents, OHC was greater among women than men, positively correlated with environmental dependence of occupation, and negatively correlated with conservative political orientation (Table 3). OHC was not associated with state, age, race, education, income, or years in current house. 


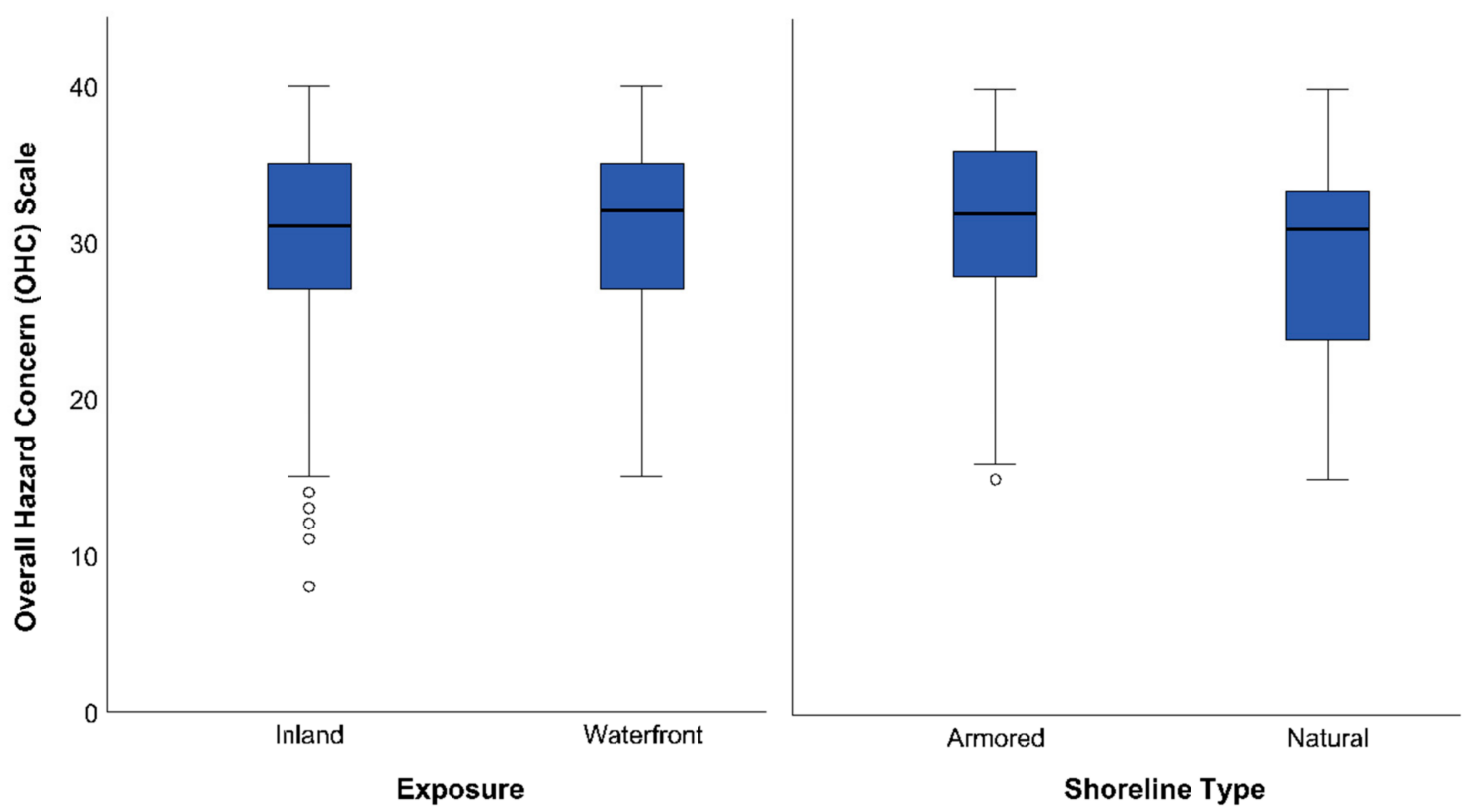

Figure 3. Boxplots showing the overall hazard concern $(\mathrm{OHC})$ scale across categories of geographic exposure and shoreline type.

Table 3. Pearson correlations between $\mathrm{OHC}$ and demographical, geographical, and property attributes (categorical variable coding is shown in Table 1 ). ${ }^{*} p \leq 0.05,{ }^{* *} p \leq 0.01,+$ Comparison not possible due to low number of non-white waterfront respondents.

\begin{tabular}{ccc}
\hline & Inland & Waterfront \\
\hline State & -0.074 & 0.044 \\
Age & 0.089 & 0.088 \\
Gender & $0.175^{* *}$ & $0.209^{* *}$ \\
Race & 0.039 & $\dagger$ \\
Education & -0.094 & 0.003 \\
Income & -0.059 & 0.04 \\
Environmental Dependence & $0.125^{*}$ & $0.167^{*}$ \\
Political Stance & $-0.145^{* *}$ & -0.116 \\
Years Current House & 0.048 & 0.051 \\
Shoreline Type & $\mathrm{n} / \mathrm{a}$ & -0.133 \\
\hline
\end{tabular}

Among waterfront residents, concern about coastal hazards was again positively correlated with categorical dependence on healthy coastal ecosystems and greater among women than men (Table 3). In this exposure, $\mathrm{OHC}$ was not associated with state, age, education, income, political stance, years in current house, or shoreline type.

Analyses of specific hazards revealed significantly different levels of concern for approximately half of all comparisons (Figure 4; Table 4). For geographic exposure, droughts and floods were of greater concern for inland residents than their waterfront counterparts; whereas, major hurricanes and erosion were cause for greater concern among waterfront respondents. Exposure was not a significant predictor of concern for category 1-2 hurricanes, sea level rise, or habitat degradation. For shoreline type, concern differed for 2 of the 8 hazards as concern for both erosion and sea level rise was greater among homeowners with armored than natural shorelines (Figure 4; Table 4). Shoreline type was not a significant predictor of concern for hurricanes, habitat degradation, floods, or droughts. 


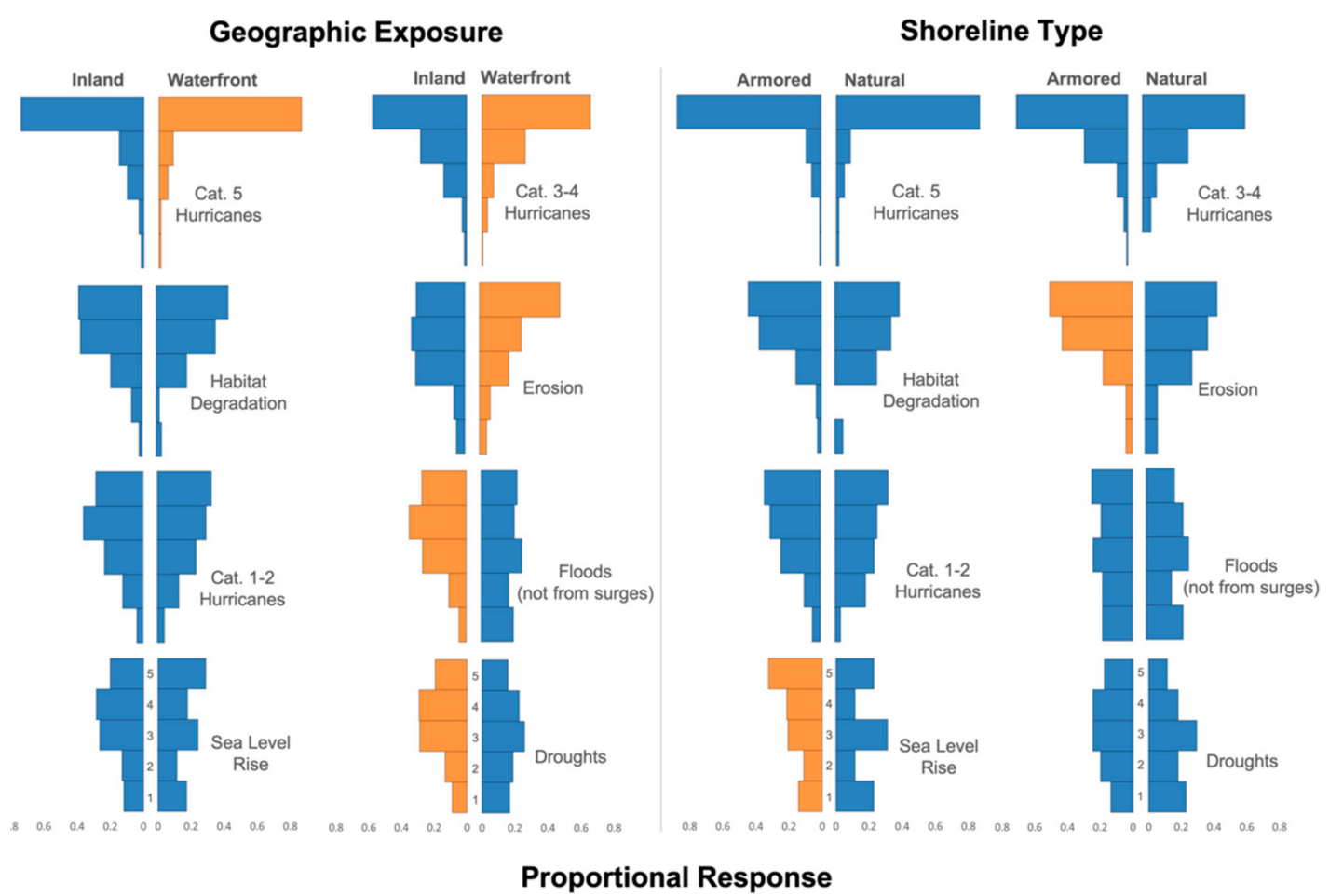

Figure 4. Frequency distributions showing inland and waterfront coastal residents' concern for 8 coastal hazards. Each plot shows proportional response for Likert scale values ranging from 1 (not at all concerned) to 5 (extremely concerned). Different colors indicate statistically significant differences at $p \leq 0.05$ with higher mean values shown in orange.

Table 4. Results of Mann-Whitney $U$ tests on concern for individual hazards for geographic exposure (inland vs. coastal) and binary shoreline type (armored vs. natural). Negative z scores on Geographic Exposure indicate a greater concern for the variable expressed by inland residents. Negative z scores for Shoreline Type indicate a greater concern for the variable by residents with armored shorelines. P-values less than 0.05 are shown in bold.

\begin{tabular}{ccccccc}
\hline & \multicolumn{3}{c}{ Geographic Exposure } & \multicolumn{3}{c}{ Shoreline Type } \\
\cline { 2 - 7 } & $\mathbf{n}$ & $\mathbf{z}$ & $\boldsymbol{p}$ & $\mathbf{n}$ & $\mathbf{z}$ & $\boldsymbol{p}$ \\
\hline Cat. 5 hurricanes & 571 & 3.09 & $\mathbf{0 . 0 0 2}$ & 172 & 0.48 & 0.962 \\
Cat. 3-4 hurricanes & 573 & 2.25 & $\mathbf{0 . 0 3 0}$ & 172 & -0.75 & 0.456 \\
Habitat degradation & 574 & 1.22 & 0.220 & 173 & -0.98 & 0.328 \\
Erosion & 573 & 4.08 & $<\mathbf{0 . 0 0 1}$ & 173 & -2.13 & $\mathbf{0 . 0 3 4}$ \\
Cat. 1-2 hurricanes & 574 & 0.47 & 0.640 & 172 & -0.88 & 0.380 \\
Floods (not from surges) & 573 & -4.17 & $<\mathbf{0 . 0 0 1}$ & 172 & -0.83 & 0.407 \\
Sea level rise & 573 & 0.18 & 0.860 & 173 & -1.90 & $\mathbf{0 . 0 3 6}$ \\
Droughts & 571 & -2.87 & $<\mathbf{0 . 0 0 1}$ & 173 & -1.66 & 0.097 \\
\hline
\end{tabular}

\section{Discussion}

Counter to our overarching hypotheses, hazard concerns were generally similar across geographic exposures and among waterfront residents with natural and armored shorelines. In regard to specific hazards, several of our findings were intuitive while others led to more nuanced conclusions. For instance, intuitively, nearly all respondents were highly concerned with major hurricanes and concern was greatest among waterfront residents. In recent history, residents in our study system have been impacted by several hurricanes and lesser storms, including Hurricanes Ivan (2004), Katrina (2005), Ike (2008), Gustav (2008), and Isaac (2012). With the exception of Ivan, which made landfall in coastal Alabama as a category 3 storm and heavily impacted the region, all of these storms made landfall 
in neighboring states to the west. Notably, the region has not been directly impacted by a category 4 or 5 storm (at landfall) in the past century, although its vulnerability was demonstrated in 2018 when category 5 Hurricane Michael devastated the central and eastern Florida Panhandle. Several other studies have also explored relationships between residential shoreline condition and outcomes of hurricanes [6,12,21,22]. For instance, Gittman and colleagues (2014) conducted geophysical surveys in the aftermath of Hurricane Irene in North Carolina and revealed that $76 \%$ of coastal properties with bulkheads suffered damage compared to none on properties with natural shorelines or hybrid structures. Additionally, Smith and Scyphers (2019) conducted household surveys following Hurricane Matthew in North Carolina and found that homes with bulkheads suffered greater damage but were also closer to the water.

A more surprising finding of our study was that waterfront homeowners with armored shorelines were generally more concerned with coastal erosion than homeowners with natural shorelines. Aside from storms, erosion control and maintenance costs are a consistent concern of waterfront residents. Shoreline erosion, as well as coastal flooding, is driven by wind patterns, wave climate, changing sea levels, storm events, boat traffic, and local drainage patterns [8]. These natural and man-made forces impose risks on coastal properties, which traditionally, coupled with the consequences of neighboring artificial structures and other social influences, has motivated shoreline armoring [11]. Naturally vegetated shorelines are dynamic by nature with gradual and episodic periods of erosion or accretion. Along armored shorelines, however, a common erosion-related concern among waterfront residents involves the overtopping of seawalls or bulkheads during high tides and storms [22]. A previous study of waterfront residents in Mobile Bay revealed that homeowners with bulkheads and similar vertical wall shorelines spend approximately twice as much as residents with natural shorelines [11]. Collectively, these studies indicate that armored shorelines may often fall short of alleviating homeowner concerns for coastal hazards.

As alternatives to traditional shoreline armoring, conservation practitioners and natural resource managers have increasingly encouraged "living shorelines" and more broadly the consideration of ecosystems for coastal protection and providing habitat and other ecosystem services [13,14]. As shorelines represent some of the most ecologically degraded places on Earth [23], the environmental reasons to pursue nature-based strategies and restore nearshore habitats for coastal protection are clear. However, from a waterfront resident's perspective, erosion of a natural shoreline involves the gradual retreat or loss of coastal vegetation, which translates to shrinking property size and potentially decreasing land value. Notably, our results indicate that overall concern for habitat degradation was the third highest of all eight hazards and only lower than Cat 3-5 hurricanes. However, numerous uncertainties and complex dynamics of shoreline decision-making remain a major impediment to expanding the use of "living shorelines" and other nature-based strategies for coastal protection.

The decision-making of waterfront residents highlights the complex risks, relationships, and trade-offs involved with balancing environmental and societal desires. Increasingly, and particularly in the wake of major coastal disasters, many scientists and stakeholders have debated the costs, benefits, and trade-offs of natural and armored shorelines and their implications for coastal sustainability. Individual responses to risk, however, are driven by perceived effectiveness, subjective risk perceptions, risk preferences (e.g., tolerance of risk), and social influences, while also limited by natural resource management and permitting policies [24,25]. With coastal hazards expected to worsen with climate change, the observations and insights of homeowners could provide important data sources and may also serve as messengers for increasing awareness and concern. Our study provides insight into these issues, but a few caveats should be noted. First, our study provides only a current snapshot of differences in concern between residents with armored versus natural shorelines, and causality could function in either direction. However, it is worth noting that the average waterfront resident in our study had lived along the water for 20 years, reflecting long-term knowledge and experience with coastal hazards. Second, our study was geographically limited to a region of the northern Gulf of Mexico. While the region's historical patterns of shoreline armoring and waterfront development are 
similar to many other places in the United States [9], additional region-specific studies are needed to understand more localized patterns of hazard concerns and other social influences on shoreline management. More broadly, our study adds to the growing body of literature highlighting the necessity of working directly with residential property owners to achieve ecosystem management goals and pursue climate adaptation [26-28].

Although living along coastlines will always involve dealing with hazards, there are many steps that individual residents and communities can implement to reduce risk and promote resilience [29-32]. Unquestionably, no shoreline protection strategy eliminates the inherent risks involved with developing new and existing property in the coastal zone, and traditional armoring strategies are unlikely to disappear. Nature-based strategies, however, could play an important role in both restoring ecosystems and hazard risk reduction in many contexts. As coastal societies experience hazards in a changing climate, the science, policy, and practice of coastal protection must continue to evolve. These efforts demand interdisciplinary expertise of architects, engineers, natural and social scientists, and practitioners, and they should involve the diverse groups of stakeholders, including shoreline residents, coastal communities, and municipalities, that are affected by coastal hazards.

Author Contributions: Conceptualization, S.B.S., M.W.B. and J.H.G.; investigation, S.B.S., M.W.B., K.L.F., J.H., L.I.J., R.L., A.G.K., C.E.L., S.P.P., B.M.W. and J.H.G.; writing-original draft, S.B.S.; writing-review and editing, S.B.S., M.W.B., K.L.F., J.H., L.I.J., R.L., A.G.K., C.E.L., S.P.P., B.M.W. and J.H.G.

Funding: This work was funded by the National Science Foundation's SEES Fellowship Program (OCE-1215825).

Acknowledgments: We are grateful to all of the coastal residents that participated in our study. Thanks to E Conley for figure preparation and S Harlan, L Senier, and the Social Equity and Environmental Justice Lab for thoughtful feedback that greatly improved an earlier version of this manuscript. This study was approved by Northeastern University's Institutional Review Board (\#12-05-17).

Conflicts of Interest: The authors declare no conflict of interest.

\section{References}

1. Burger, J.; O'Neill, K.M.; Handel, S.N.; Hensold, B.; Ford, G. The shore is wider than the beach: Ecological planning solutions to sea level rise for the Jersey Shore, USA. Landsc. Urban Plan. 2017, 157, $512-522$. [CrossRef]

2. Landry, C.E. Coastal Erosion as a Natural Resource Management Problem: An Economic Perspective. Coast. Manag. 2011, 39, 259-281. [CrossRef]

3. Narayan, S.; Beck, M.W.; Reguero, B.G.; Losada, I.J.; van Wesenbeeck, B.; Pontee, N.; Sanchirico, J.N.; Ingram, J.C.; Lange, G.-M.; Burks-Copes, K.A. The Effectiveness, Costs and Coastal Protection Benefits of Natural and Nature-Based Defences. PLoS ONE 2016, 11, e0154735. [CrossRef] [PubMed]

4. Arkema, K.K.; Guannel, G.; Verutes, G.; Wood, S.A.; Guerry, A.; Ruckelshaus, M.; Kareiva, P.; Lacayo, M.; Silver, J.M. Coastal habitats shield people and property from sea-level rise and storms. Nat. Clim. Chang. 2013, 3, 913. [CrossRef]

5. Narayan, S.; Beck, M.W.; Wilson, P.; Thomas, C.J.; Guerrero, A.; Shepard, C.C.; Reguero, B.G.; Franco, G.; Ingram, J.C.; Trespalacios, D. The Value of Coastal Wetlands for Flood Damage Reduction in the Northeastern USA. Sci. Rep. 2017, 7, 9463. [CrossRef]

6. Tomiczek, T.; Kennedy, A.; Zhang, Y.; Owensby, M.; Hope, M.E.; Lin, N.; Flory, A. Hurricane damage classification methodology and fragility functions derived from Hurricane Sandy's effects in Coastal New Jersey. J. Waterway Port Coast. Ocean Eng. 2017, 143, 04017027. [CrossRef]

7. Kittinger, J.N.; Ayers, A.L. Shoreline Armoring, Risk Management, and Coastal Resilience Under Rising Seas. Coast. Manag. 2010, 38, 634-653. [CrossRef]

8. National Research Council; Division on Earth and Life Studies; Ocean Studies Board; Committee on Mitigating Shore Erosion Along Sheltered Coasts. Mitigating Shore Erosion Along Sheltered Coasts; National Academies Press: Washington, DC, USA, 2007; ISBN 9780309103466.

9. Gittman, R.K.; Fodrie, F.J.; Popowich, A.M.; Keller, D.A.; Bruno, J.F.; Currin, C.A.; Peterson, C.H.; Piehler, M.F. Engineering away our natural defenses: An analysis of shoreline hardening in the US. Front. Ecol. Environ. 2015, 13, 301-307. [CrossRef] 
10. Bilkovic, D.M.; Roggero, M.M. Effects of coastal development on nearshore estuarine nekton communities. Mar. Ecol. Prog. Ser. 2008, 358, 27-39. [CrossRef]

11. Scyphers, S.B.; Picou, J.S.; Powers, S.P. Participatory conservation of coastal habitats: The importance of understanding homeowner decision making to mitigate cascading shoreline degradation. Conserv. Lett. 2015. [CrossRef]

12. Smith, C.S.; Gittman, R.K.; Neylan, I.P.; Scyphers, S.B. Hurricane damage along natural and hardened estuarine shorelines: Using homeowner experiences to promote nature-based coastal protection. Mar. Policy 2017. [CrossRef]

13. Gittman, R.K.; Peterson, C.H.; Currin, C.A.; Fodrie, F.J.; Piehler, M.F.; Bruno, J.F. Living shorelines can enhance the nursery role of threatened estuarine habitats. Ecol. Appl. 2016, 26, 249-263. [CrossRef] [PubMed]

14. Scyphers, S.B.; Powers, S.P.; Heck, K.L., Jr.; Byron, D. Oyster reefs as natural breakwaters mitigate shoreline loss and facilitate fisheries. PLoS ONE 2011, 6, e22396. [CrossRef] [PubMed]

15. Piazza, B.P.; Banks, P.D.; La Peyre, M.K. The Potential for Created Oyster Shell Reefs as a Sustainable Shoreline Protection Strategy in Louisiana. Restor. Ecol. 2005, 13, 499-506. [CrossRef]

16. Smith, C.S.; Puckett, B.; Gittman, R.K.; Peterson, C.H. Living shorelines enhanced the resilience of saltmarshes to Hurricane Matthew (2016). Ecol. Appl. 2018, 28, 871-877. [CrossRef]

17. Shepard, C.C.; Crain, C.M.; Beck, M.W. The protective role of coastal marshes: A systematic review and meta-analysis. PLoS ONE 2011, 6, e27374. [CrossRef]

18. Reguero, B.G.; Beck, M.W.; Bresch, D.N.; Calil, J.; Meliane, I. Comparing the cost effectiveness of nature-based and coastal adaptation: A case study from the Gulf Coast of the United States. PLoS ONE 2018, 13, e0192132. [CrossRef]

19. Beck, M.W.; Brumbaugh, R.D.; Airoldi, L.; Carranza, A. Oyster reefs at risk and recommendations for conservation, restoration, and management. Bioscience 2011. [CrossRef]

20. Dillman, D.A.; Smyth, J.D.; Christian, L.M. Internet, Phone, Mail, and Mixed-Mode Surveys: The Tailored Design Method; John Wiley \& Sons: Hoboken, NJ, USA, 2014; ISBN 9781118921302.

21. Smith, C.S.; Scyphers, S. Past hurricane damage and flood zone outweigh shoreline hardening for predicting residential-scale impacts of Hurricane Matthew. Environ. Sci. Policy 2019, 101, 46-53. [CrossRef]

22. Gittman, R.K.; Popowich, A.M.; Bruno, J.F.; Peterson, C.H. Marshes with and without sills protect estuarine shorelines from erosion better than bulkheads during a Category 1 hurricane. Ocean Coast. Manag. 2014, 102, 94-102. [CrossRef]

23. Halpern, B.S.; Walbridge, S.; Selkoe, K.A.; Kappel, C.V.; Micheli, F.; D'Agrosa, C.; Bruno, J.F.; Casey, K.S.; Ebert, C.; Fox, H.E.; et al. A global map of human impact on marine ecosystems. Science 2008, 319, 948-952. [CrossRef]

24. Ruckelshaus, M.H.; Guannel, G.; Arkema, K.; Verutes, G.; Griffin, R.; Guerry, A.; Silver, J.; Faries, J.; Brenner, J.; Rosenthal, A. Evaluating the Benefits of Green Infrastructure for Coastal Areas: Location, Location, Location. Coast. Manag. 2016, 44, 504-516. [CrossRef]

25. Touili, N.; Baztan, J.; Vanderlinden, J.-P.; Kane, I.O.; Diaz-Simal, P.; Pietrantoni, L. Public perception of engineering-based coastal flooding and erosion risk mitigation options: Lessons from three European coastal settings. Coast. Eng. 2014, 87, 205-209. [CrossRef]

26. Armstrong, A.; Stedman, R.C. Landowner willingness to implement riparian buffers in a transitioning watershed. Landsc. Urban Plan. 2012, 105, 211-220. [CrossRef]

27. Cook, E.M.; Hall, S.J.; Larson, K.L. Residential landscapes as social-ecological systems: A synthesis of multi-scalar interactions between people and their home environment. Urban Ecosyst. 2012, 15, 19-52. [CrossRef]

28. Hunter, M.C.R.; Brown, D.G. Spatial contagion: Gardening along the street in residential neighborhoods. Landsc. Urban Plan. 2012, 105, 407-416. [CrossRef]

29. Flint, C.G.; Luloff, A.E. Natural Resource-Based Communities, Risk, and Disaster: An Intersection of Theories. Soc. Nat. Resour. 2005, 18, 399-412. [CrossRef]

30. Leuttich, R.A.; Baecher, G.B.; Bell, S.B.; Berke, P.R.; Corotis, R.B.; Cox, D.T.; Dalrymple, R.A.; MacDonald, T.; Nordstrom, K.F.; Polasky, S.; et al. Reducing Coastal Risk on the East and Gulf Coasts; The National Academies Press: Washington, DC, USA, 2014. 
31. Picou, J.S.; Marshall, B.K. Contemporary Conceptions of Environmental Risk: Implications for Resource Management and Policy. Sociol. Pract. 2002, 4, 293-313. [CrossRef]

32. Spalding, M.D.; McIvor, A.L.; Beck, M.W.; Koch, E.W.; Möller, I.; Reed, D.J.; Rubinoff, P.; Spencer, T.; Tolhurst, T.J.; Wamsley, T.V.; et al. Coastal ecosystems: A critical element of risk reduction. Conserv. Lett. 2014, 7, 293-301. [CrossRef] 